\title{
An Action Research on the Application of TED Talks in Teaching English as a Foreign Language (EFL)
}

\author{
Jianying Yue, Xiaoli Song \\ North China Electric Power University, Beijing, China
}

\begin{abstract}
For teaching English as a foreign language (EFL), English listening textbooks are always blamed for artificial lectures for teaching academic listening skills, and students complain about the listening, repeating, and filling in the blank way of teaching. To better solve these problems, the authors conducted a three-cycle of action research and tended to answer these two questions: (1) Are TED talks appropriate materials for use in class? (2) How do we use TED talks effectively in class? The action research showed that with certain selection criteria, TED talks can be appropriate materials for use in class. The way to use them varies depending on the combination of students' needs and teaching objectives.
\end{abstract}

Keywords: teaching English as a foreign language (EFL), action research, TED talks

\section{Research Background}

English listening is always blamed as a boring lesson. As we know that students always feel trouble before trying listening lessons. Most students think that listening class is always synonymous with listening, repeating, or filling in the blanks or answering questions then the class should be quiet. One of the reasons for this is that listening textbooks are about artificial lectures for teaching academic listening skills. So, the teachers tend to try their utmost to make the class more interactive by choosing the right materials to add to the teaching curriculum.

TED (Technology, Entertainment, Design) talks provide ample opportunities to develop and refine students' English speaking and comprehension abilities in an engaging and informative way. As a nonprofit forum devoted to spreading ideas, TED talks are usually in the form of short, powerful presentations (20 minutes or less). In recent years, TED talks have grown into a global platform, where ideas and information converge. Ahluwalia (2018) studied the use lessons based on TED talks and concluded that TED talks can be used to make the language lessons interesting and enjoyable, though care needs to be taken while selecting the talk, planning the pre- and post-listening, and viewing activities and the time management. Leopold (2016) assigned students to listen to short clips from some TED talks to learn techniques to make supporting points memorable, and then students use them in their own speeches. Some studies focus on TED talks' important role in facilitating listening (Elk, 2014).

Jianying Yue, Master in Arts, Lecturer, North China Electric Power University, Beijing, China.

Xiaoli Song, Master in Arts, Lecturer, North China Electric Power University, Beijing, China.

Funding: This paper is supported by North China Electric Power University Teaching Research Project Number (XM1907409). 
Higher Education Press in China published a series of viewing, listening, and speaking textbooks based on TED talks and they are one of Chinese students' preferred textbooks. A MOOC called TED Viewing, Listening, and Speaking by Xi' an Jiaotong University is available in China University MOOC, a leading MOOC platform in China.

The reasons why I use TED talks in listening and speaking class are as follows. First, it is the language authenticity that teachers value. Current listening courses have been blamed for lack of authenticity in that they seem to be using institutionally-mandated commercial textbooks that are based on recordings of artificial "lectures" performed by actors (Elk, 2014). The lectures that accompany L2 textbooks are a form of modified input that has many of the characteristics of child-directed speech in its slower and more careful phonology, simplified morphology, and simplified semantics (Rost, 2011).

The literature strongly indicates that EFL listening curriculum is overly dependent upon artificial lectures for teaching academic listening skills, a predicament for instructors that Field (2008) aptly compared to spoon-feeding a child a diet of baby food and then marveling that they cannot digest adult food. There is evidence that intermediate learners develop better listening comprehension ability in cultural awareness training courses when authentic materials are used as the medium of instruction instead of inauthentic materials (Barekat \& Nobakhti, 2014) suggesting that instructors should look for opportunities to include authentic materials in the curriculum to address many learning-outcome goals.

Second, contents of selected TED talks can perfectly go align with the unit theme. TED talks have a wide range of topics, such as science discovery, education, social change, personal growth. They will never fail to intrigue students with diverse interests. Besides, most of the talks are up to date, and provide audience with the most recent findings and discoveries, which can best make up for textbooks' obsolescence. TED talks are delivered in the style of a university lecture, often accompanied by Power Point slide shows as are lectures in many university classrooms. They are all videos which necessitate the parsing of visual as well as audio input. The visual aspect of videos can enhance comprehension (Wagner, 2013), though it can also overwhelm a learner's limited L2 working memory and complicate comprehension (Cross, 2011) due to the increase in cognitive load with the addition of visual input when compared to audio alone (Homer, Plass, \& Blake, 2008).

Regular viewing of TED talks provides opportunities to develop strategies for processing visual input that is synchronous, but not identical to aural input. What is more, the length of TED talks ranges from 4 to 20 minutes, which fit perfectly in learners' attention span, and is also feasible for classroom schedule.

Selecting quality materials includes determining the degree to which they are consistent with the goals, principles, and criteria of the course curriculum. The content of the TED talks should be relevant to the reason for showing the video, that is, to be solidly embedded in a meaningful context, satisfy the professional interests of the students, and provide real life examples of doing business in an international environment. In addition, the content of the TED talks should have an educational value. The problems discussed should develop the learners' linguistic and professional competencies and expand their outlook by acquainting them with business practices from around the world. The sequence of TED talks should fit in with the overall goals of the course, introduce, or expand on a theme that is already part of the curriculum (Ciccone, 1995).

The popularity of the TED talk is measured in the number of views. The view count gives a reflection of how the audience responded to the information provided.

The length of the TED talks should be determined by the students' language proficiency. Teachers might explore talks of different durations as set by TED.com (0-6 minutes, 6-12 minutes, 12-18 minutes, and 18+ 
minutes). With low-level students, for example, a lengthy video material with many tasks could be discouraging. If EFL students are not yet familiar with lengthy transcripts then the shorter ones might work better for them.

The difficulty level of TED talk content can be determined by using Ted Corpus Search Engine (TCSE) (Yoichiro, 2015). TCSE is a free online search engine specializing in exploring transcripts of TED talks. It has been created for educational and scientific purposes. The database is big enough even though the number of talks might be less than displayed on TED.com.

Taking the above mentioned criteria into consideration, I incorporated some of the TED talks into the teaching curriculum.

\section{Action Research}

For a teacher, who is reflective and committed to developing as a thinking professional, action research is an appealing way to look more closely at puzzling classroom issues or to delve into teaching dilemmas.

Action research is a self-reflective, systematic and critical approach to enquiry by participants who are at the same time members of the research community. The aim is to identity problematic situations or issues considered by the participants to be worthy of investigation in order to bring about critically informed changes in practice. (Burns, in Corn well, 1999, p. 5)

\section{Research Questions}

I conducted a survey on the audio and video materials of the textbook (New Horizon College English Book 4, 2015) and 50 students participated in it. The result shows that $53 \%$ of students complain about the out-dated contents of the textbook, and $20 \%$ of students think the speakers speak in such a natural way that they can not follow them. To help make up for the shortcoming of the textbook, I tried to integrate TED talks as part of the teaching material and explore the following questions: (1) Are TED talks appropriate materials for use in class? (2) How do we use them effectively in class?

The research lasts for 15 weeks, with each 5 weeks as a cycle.

Table 1

Cycle 1

\begin{tabular}{|c|c|c|c|}
\hline Topic of each unit & TED talks & Teaching procedures & Teaching objectives \\
\hline \multirow{3}{*}{$\begin{array}{l}\text { Unit } 1 \text { Good and Dad } \\
\text { Behavior in Public Places }\end{array}$} & \multirow{3}{*}{$\begin{array}{l}\text { Moral behavior in animals (Frans de } \\
\text { Wall, Primatologist, studies primate } \\
\text { social behavior) }\end{array}$} & $\begin{array}{l}\text { The teacher explains the difficult } \\
\text { words and expressions and } \\
\text { introduces the speaker. }\end{array}$ & Scaffold \\
\hline & & $\begin{array}{l}\text { Students watch this talk and } \\
\text { generalize the main idea. }\end{array}$ & $\begin{array}{l}\text { Practice Listening } \\
\text { comprehension }\end{array}$ \\
\hline & & Students discuss in-depth questions. & Develop speaking ability \\
\hline \multirow{3}{*}{$\begin{array}{l}\text { Unit } 2 \text { Longest-living } \\
\text { Communities in the World }\end{array}$} & \multirow{3}{*}{$\begin{array}{l}\text { The secret to living longer may be } \\
\text { your social life (Susan Pinker, } \\
\text { developmental psychologist, how } \\
\text { in-person social interactions are not } \\
\text { only necessary for human happiness } \\
\text { but also could be a key to health and } \\
\text { longevity) }\end{array}$} & $\begin{array}{l}\text { The teacher explains the difficult } \\
\text { words and expressions and } \\
\text { introduces the speaker. }\end{array}$ & Scaffold \\
\hline & & $\begin{array}{l}\text { Students watch this talk and } \\
\text { generalize the main idea. }\end{array}$ & $\begin{array}{l}\text { Practice listening } \\
\text { comprehension }\end{array}$ \\
\hline & & Students discuss in-depth questions. & Develop speaking ability \\
\hline
\end{tabular}

\section{Observations and Reflections}

The attempt to integrate TED talks into listening speaking and viewing class is a good try. Students wrote this in their blogs: 
TED talks are really intriguing. I learned for the first time that even animals can show moral behavior such as compassion, sharing. They are much clever than I have thought before.

TED talks are eye-opening. Not only do I practice listening skills but also increase my knowledge.

When talking about factors that contribute to longevity, the traditional picture is healthy diet, regular exercises, genes etc. Most of the time we just underestimate the value of social interactions. These findings of Susan are really novel and thought provoking.

However, through class observations and interviews with students, I found some problems as well. Some students find it difficult in fully understanding these talks in class, which is only about twice watching. Thus these students can only follow the teacher blindly, which leads to an ineffective learning process. It takes about 35 minutes to watch and lecture on the talks contents, and leaves only about 15 minutes for students to communicate their understanding of the talks. It reduces the students' time of discussion.

To solve the above mentioned problems, I designed the second cycle, which is also 5 weeks. The difference is that I posted the TED talks on U campus (U campus is an online learning platform) and let students watch the ted before they come to class. In the class we do the following class activities as listed in the table.

Table 2

Cycle 2

\begin{tabular}{|c|c|c|c|}
\hline Topic of each unit & TED talks & Teaching procedures & Teaching objectives \\
\hline \multirow{3}{*}{ Unit 3 Niche Holiday } & \multirow{3}{*}{$\begin{array}{l}\text { The secret I find on the } \\
\text { mysterious ocean floor (Laura } \\
\text { Robinson, ocean scientist, find } \\
\text { clues of what might happen in } \\
\text { the future) }\end{array}$} & $\begin{array}{l}\text { Students answer basic content } \\
\text { questions }\end{array}$ & Improve listening comprehension \\
\hline & & $\begin{array}{l}\text { Students discuss in group the theme } \\
\text { of the talk }\end{array}$ & $\begin{array}{l}\text { Promote communicative skills and } \\
\text { inspire in-depth discussion on the } \\
\text { talk }\end{array}$ \\
\hline & & $\begin{array}{l}\text { Students write reflections on the } \\
\text { talk in their blogs }\end{array}$ & Practice critical thinking skills \\
\hline \multirow{3}{*}{ Unit 4 Happiness } & \multirow{3}{*}{$\begin{array}{l}\text { How to buy happiness (Michel } \\
\text { Norton, social science } \\
\text { researcher, how money can } \\
\text { indeed buy happiness-when } \\
\text { you don't spend it on yourself) }\end{array}$} & $\begin{array}{l}\text { Students answer basic content } \\
\text { questions }\end{array}$ & Improve listening comprehension \\
\hline & & $\begin{array}{l}\text { Students discuss in group the theme } \\
\text { of the talk }\end{array}$ & $\begin{array}{l}\text { Promote communicative skills and } \\
\text { inspire in-depth discussion on the } \\
\text { talk }\end{array}$ \\
\hline & & $\begin{array}{l}\text { Students write reflections on the } \\
\text { talk in their blogs }\end{array}$ & Practice critical thinking skills \\
\hline
\end{tabular}

\section{Observations and Reflections}

With sufficient time to review these talks, students have better understanding of each talk. Most of the well-prepared students can answer the basic contents questions well. And many of them enjoy the process of discussion, in which they share their unique understanding of each topic. To further their thinking on the issue, they write their reflections on the blogs.

I have never had the opportunity to see what life in the ocean look like until I watch Ms. Laura's ted presentation. It is really fascinating. However, I am also worried about the changes it suffered from human actions.

Money can buy happiness? Yes, it is true. According to social scientist Michael Norton, money can buy happiness, so long as you spend it on others instead of on yourselves!

I have watched the talk several times, I still can not understand some part of it . As a result, my participation in discussion is limited. I need more help from the teacher.

How I wish I could make presentations as the speakers do! I tend to get nervous, stumble over words, and what is worse, my mind goes blank when I am standing on the stage in front of a large audience. 
With students' increasing interest in TED talks, some of them showed strong desire to be speakers themselves. So I think it is the right time for me to push them to produce comprehensible output based on adequate input.

The term "input" is used to describe the language that is available to learners which can be spoken or written. Input serves as the data which the learners must use to determine the rules of the target language (Ellis, 1986). From the phrase "Lack of understanding, no learning can take place" (Gass, 1994), it seems clear that the right kind of input is one of the significant elements for second language learners to acquire their second language.

Krashen claimed that language is not "soaked up" so second language learners must understand messages that are conveyed. Learners are able to understand massages just one step beyond their current knowledge, which means the right kind of input. The right kind of input which language learners are exposed to must be at the " $i+1$ " level in terms of acquiring second language acquisition, which " $i$ " is defined as a learner's current knowledge and the next stage is $i+1$ (Gass, 1994). The term "output" or "comprehensible output" will allow language learners to use the language they know in a productive way (Yule, 2006). Comprehensible output refers to the need for language learners to be "pushed toward the delivery of a message that is not only conveyed, but that is conveyed precisely, coherently, and appropriately".

In China, university freshmen are just such learners who typically have a relatively large amount of receptive knowledge but limited experience using English for communication. To better push students to produce comprehensible output, I carried out the 3rd cycle of action research, which also lasted for 5 weeks. This cycle featured the combination of blended learning model, where students finished learning and doing exercises online, and in the flipped class, they are encouraged to do presentations based on the given topic.

Table 3

Cycle 3

\begin{tabular}{|c|c|c|c|}
\hline Topic of each unit & TED talks & Teaching procedures & Teaching objectives \\
\hline \multirow[b]{2}{*}{ Unit 5 Money } & \multirow{2}{*}{$\begin{array}{l}\text { An escape from poverty (Jacqueline } \\
\text { Novogratz, founder of Acumen, a } \\
\text { non-profit organization that funds } \\
\text { projects to improve the lives of poor } \\
\text { people) }\end{array}$} & $\begin{array}{l}\text { Students watch TED talks and } \\
\text { do exercises online. }\end{array}$ & $\begin{array}{l}\text { Students can understand the } \\
\text { presentation and critically } \\
\text { think of the topic. }\end{array}$ \\
\hline & & $\begin{array}{l}\text { In flipped class, students give } \\
\text { their own presentations based } \\
\text { on the topic of "An escape } \\
\text { from poverty." }\end{array}$ & $\begin{array}{l}\text { Students practice their } \\
\text { presentation skills esp. } \\
\text { Persuasion. }\end{array}$ \\
\hline \multirow{2}{*}{ Unit 6 Success } & \multirow{2}{*}{$\begin{array}{l}\text { Don't eat the marshmallow! (Joachim } \\
\text { de Posada, a writer and motivational } \\
\text { coach from Puerto Rico. He helps } \\
\text { companies and teams to find deep and } \\
\text { lasting reasons to succeed) }\end{array}$} & $\begin{array}{l}\text { Students watch TED talks and } \\
\text { do exercises online. }\end{array}$ & $\begin{array}{l}\text { Students can understand the } \\
\text { presentation and critically } \\
\text { think of the topic. }\end{array}$ \\
\hline & & $\begin{array}{l}\text { In flipped class, students give } \\
\text { their own presentations based } \\
\text { on the topic of "success". }\end{array}$ & $\begin{array}{l}\text { Students practice their } \\
\text { presentation skills esp. body } \\
\text { movement and gesture. }\end{array}$ \\
\hline
\end{tabular}

\section{Observations and Reflections}

After this cycle, students reflected on their gains in the flipped classes.

By imitating the speakers' body language, I found myself confident standing in front of the class, and I can use English to express my own opinion. It seemed that I was also invited to TED.

Thank my teacher for offering the opportunity to horn my public speaking skills. However, it is a giant challenge for me. It was worthwhile to experience the stage fright. I am confident that could be better next time. 


\section{Conclusion}

With 3 cycles of action research, I tend to prove that TED talks are useful resources for English listening and speaking class, and can be effective supplements to college listening textbooks. With its authentic language input, interesting and insightful ideas, students can be motivated to develop learner independence. However, special attention should be paid to the degree of comprehensibility of the TED talks, in case they baffle students and lead to the loss of confidence. What is more, proper classroom activities are needed to encourage students to put their comprehensible input into productive output.

Though the 3 cycles of action research was fruitful, some problems remained to be solved in further teaching practice. First, the gap of students' competence in delivering presentation can not be ignored, and more efforts need to be made to help the weaker students. Second, an effective system for assessing students' presentations is in urgent need to be incorporated into the teaching syllabus.

\section{References}

Burns, A. (2011). Doing action research in English language teaching: A guide for practitioners. New York: Foreign Language Teaching and Research Press.

Barekat, B., \& Nobakhti, H. (2014). The effect of authentic and inauthentic materials in cultural awareness training on EFL learners' listening comprehension ability. Theory and Practice in Language Studies, 4, 1058-1065.

Elk, C. K. (2014). Beyond mere listening comprehension: Using TED talks and metacognitive activities to encourage awareness of errors. International Journal of Innovation in English Language Teaching \& Research, 3(2), 215-220.

Ciccone, A. (1995). Teaching with authentic video: Theory and practice. In F. R. Eckman, D. D. Highland, P. W. Lee, J. Milman, and R. R. Weber (Eds.), Second language acquisition: Theory and pedagogy (pp. 203-218). Mahwa, NJ: Psychology Press.

Cross, J. (2011). Comprehending news video texts: The influence of the visual content. Language Teaching \& Technology, 15, 44-68.

Ellis, R. (1986). Understanding second language acquisition. Oxford: The Alden Press

Field, J. (2008). Listening in the language classroom. Cambridge: Cambridge University Press.

Gass, S. M., \& Selinker, L. (1994). Second language acquisition: An introductory course. New Jersey: Lawrence Erlbaum Association, Inc.

Ahluwalia, G. (2018). Students' perceptions on the use of TED talks for English language learning language in India. India's Higher Education Authority UGC Approved List of Journals, 18, 12.

Homer, B., Plass, J. L., \& Blake, L. (2008). The effects of video on cognitive load and social presence in multimedia-learning. Computers in Human Behavior, 24, 786-797.

Leopold, L. (2016). Honing EAP learners' public speaking skills by analyzing TED talks. TESL Canada Journal, 33(2), 46-58.

Rost, M. (2011). Teaching and researching listening (2nd ed.). Harlow, England: Pearson.

Wagner, E. (2013). An investigation of how the channel of input and access to test questions affect L2 listening test performance. Language Assessment Quarterly, 10, 178-195.

Yoichiro, H. (2015). Design and implementation of an online corpus of presentation transcripts of TED talks. Procedia: Social and Behavioral Sciences, 198(24), 174-182.

Yule, G. (2006). The study of language. Cambridge: Cambridge University Press. 